\title{
Article \\ Photoprotective Role of Photosynthetic and Non-Photosynthetic Pigments in Phillyrea latifolia: Is Their "Antioxidant" Function Prominent in Leaves Exposed to Severe Summer Drought?
}

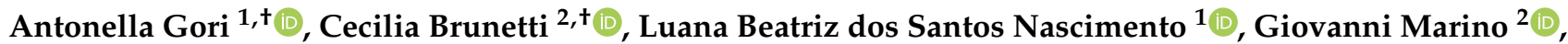

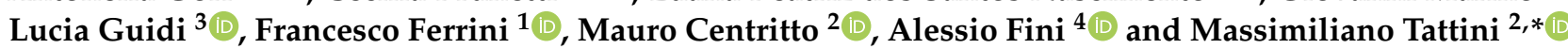 \\ 1 Department of Agriculture, Food, Environment and Forestry (DAGRI), University of Florence, \\ 50019 Sesto Fiorentino, Italy; antonella.gori@unifi.it (A.G.); luanabeatriz.dossantosnascimento@unifi.it (L.B.d.S.N.); \\ francesco.ferrini@unifi.it (F.F.) \\ 2 Institute for Sustainable Plant Protection (IPSP), National Research Council of Italy, 50019 Sesto Fiorentino, Italy; \\ cecilia.brunetti@ipsp.cnr.it (C.B.); giovanni.marino@ipsp.cnr.it (G.M.); mauro.centritto@cnr.it (M.C.) \\ 3 Department of Agriculture, Food and Environment, University of Pisa, 56124 Pisa, Italy; lucia.guidi@unipi.it \\ 4 Department of Agricultural and Environmental Sciences-Production, Landscape, Agroenergy, \\ University of Milan, 20122 Milan, Italy; alessio.fini@unimi.it \\ * Correspondence: massimiliano.tattini@ipsp.cnr.it \\ $\dagger$ These authors contributed equally to the manuscript.
}

Citation: Gori, A.; Brunetti, C.; dos Santos Nascimento, L.B.; Marino, G.; Guidi, L.; Ferrini, F.; Centritto, M.; Fini, A.; Tattini, M. Photoprotective Role of Photosynthetic and Non-Photosynthetic Pigments in Phillyrea latifolia: Is Their "Antioxidant" Function Prominent in Leaves Exposed to Severe Summer Drought? Int. J. Mol. Sci. 2021, 22, 8303. https:// doi.org/10.3390/ijms22158303

Academic Editors: Marcello Iriti, Elena Maria Varoni and Sara Vitalini

Received: 1 July 2021

Accepted: 29 July 2021

Published: 2 August 2021

Publisher's Note: MDPI stays neutral with regard to jurisdictional claims in published maps and institutional affiliations.

Copyright: (c) 2021 by the authors. Licensee MDPI, Basel, Switzerland. This article is an open access article distributed under the terms and conditions of the Creative Commons Attribution (CC BY) license (https:// creativecommons.org/licenses/by/ $4.0 /)$
Abstract: Carotenoids and phenylpropanoids play a dual role of limiting and countering photooxidative stress. We hypothesize that their "antioxidant" function is prominent in plants exposed to summer drought, when climatic conditions exacerbate the light stress. To test this, we conducted a field study on Phillyrea latifolia, a Mediterranean evergreen shrub, carrying out daily physiological and biochemical analyses in spring and summer. We also investigated the functional role of the major phenylpropanoids in different leaf tissues. Summer leaves underwent the most severe drought stress concomitantly with a reduction in radiation use efficiency upon being exposed to intense photooxidative stress, particularly during the central hours of the day. In parallel, a significant daily variation in both carotenoids and phenylpropanoids was observed. Our data suggest that the morning-to-midday increase in zeaxanthin derived from the hydroxylation of $B$-carotene to sustain non-photochemical quenching and limit lipid peroxidation in thylakoid membranes. We observed substantial spring-to-summer and morning-to-midday increases in quercetin and luteolin derivatives, mostly in the leaf mesophyll. These findings highlight their importance as antioxidants, countering the drought-induced photooxidative stress. We concluded that seasonal and daily changes in photosynthetic and non-photosynthetic pigments may allow $P$. latifolia leaves to avoid irreversible photodamage and to cope successfully with the Mediterranean harsh climate.

Keywords: carotenoids; dihydroxy B-ring-substituted flavonoids; drought stress; epidermal and mesophyll flavonoids; hydroxycinnamates; photoprotection; zeaxanthin

\section{Introduction}

The ability of plants to cope successfully with a range of environmental stressors depends on a suite of integrated and modular adjustments involving morphoanatomical, physiological and biochemical traits [1-3]. These adjustments are particularly significant for the survival, rather than for the profitable growth, of plants inhabiting highly unfavorable ecosystems, such as the Southern Mediterranean basin [4-6]. This concept is consistent with the fact that species evolved in adverse Mediterranean regions, particularly the sclerophyllous evergreens, invest a large portion of the fixed carbon for leaf construction and for the biosynthesis of carbon-based secondary compounds, rather than sustaining new growth [7-9]. Mediterranean evergreen species display low $\mathrm{CO}_{2}$ assimilation rates (on a leaf area basis), even under the most favorable environmental conditions [4]. Hence, they 
are daily exposed to an excess of solar irradiance and to the consequent photooxidative stress $[10,11]$.

Excessive light stress may become particularly severe during the central hours of the day, especially in summer, when the scarcity of water availability together with the high temperatures substantially limit the leaf's ability to use the radiant energy for photosynthesis $[4,12,13]$. The necessity of coping with an excess of solar irradiance conforms to evergreen sclerophyllous shrubs displaying constitutive morphoanatomical features that are well suited to limiting the deeper penetration of additional photons in the more sensitive leaf tissues $[8,14]$. Some of these features include leaves that grow at a steep angle, usually with a thick cuticle and mesophyll (at full developmental stages), and covered by a dense indumentum of light-reflecting and absorbing structures (i.e., a wide array of glandular and non-glandular trichomes) [7-9].

Additionally, effective photoprotection might be provided by specialized secondary metabolites, which may serve the dual function of "avoiding" (limiting) and/or "countering" photooxidative damage [15-18]. This is the case of xanthophylls, whose biosynthesis is strongly modulated by light $[19,20]$. For example, violaxanthin cycle pigments (VAZ) are involved in the thermal dissipation of excessive energy through non-photochemical quenching (NPQ), as well as in reducing the oxidative load inside the chloroplasts $[15,21-23]$. Indeed, there is evidence that zeaxanthin may behave as an antioxidant in chloroplasts of leaves exposed for a long time to full sunlight $[16,24,25]$, when the pool of VAZ may saturate the binding sites of the light-harvesting chlorophyll-protein complexes [26,27]. Zeaxanthin may increase the rigidity of the thylakoid membranes, thus reducing peroxidative damage [21,28-30]. In addition, it can quench the singlet oxygen produced at considerable rates under drought stress-induced severe excesses of light [22]. In fact, the biosynthesis of zeaxanthin occurs not only through de-epoxidation of violaxanthin but also through hydroxylation of $\beta$-carotene under severe drought stress [25,31-33].

Pigments biosynthesized through the phenylpropanoid pathway (which is under strict light control [17,34-36]), particularly the vast class of flavonoids, may also constitute effective shields against the most energetic solar wavelengths. Additionally, they can act as scavengers of a wide range of reactive oxygen species (ROS), especially when the light stress becomes severe [37-40]. Indeed, flavonoids are found in very high concentrations in the epidermal cells (due to the small volume in which they are "dissolved"), but they also accumulate to great extent in the mesophyll of leaves adapted or long acclimated to high solar irradiance $[14,18,37,41,42]$. There is compelling proof that flavonoids located in the vacuoles, chloroplasts and nuclei of mesophyll cells may effectively scavenge the ROS produced during severe light excess $[39,40,42]$. This dual role of flavonoids in photoprotection (shields and ROS scavengers) is supported by the observation that high solar irradiance, even in the absence of UV radiation, leads to an enhanced biosynthesis of dihydroxy Bring-substituted flavonoids, whereas it barely affects the biosynthesis of the monohydroxy B-ring-substituted forms (for review articles, see [18,40,42]). Indeed, dihydroxy flavonoids have considerably greater ability to scavenge ROS but very similar UV-absorbing capacity if compared with monohydroxy flavonoids [42].

Mechanisms of photoprotection are activated on a daily basis, as has long been reported for diurnal variations in the concentration and composition of VAZ pigments, thereby sustaining thermal dissipation of excessive radiant energy through NPQ [43-45]. Less is known about the seasonal variations in the carotenoid concentration and composition of Mediterranean plants. However, in a range of plant species, evidence of both winter-to-summer and spring-to-summer decreases in the concentration of these molecules (on a leaf mass basis) have been reported [46-51]. Much less is known about seasonal and daily variations in phenylpropanoid contents [50-55]. Nonetheless, recent findings of significant dawn-to-midday changes in UV-A transmittance, particularly in species growing in warm areas [56,57], suggest that flavonoids other than carotenoids may have diurnal plasticity [58]. Although the extent to which phytochemicals, particularly phenylpropanoids, vary on a daily basis is strongly species-dependent [59], Barnes et al. [56] 
have provided evidence that diurnal adjustment in ultraviolet sunscreen protection is widespread among higher plants.

Considering this scenario, we hypothesize that both carotenoids and phenylpropanoids may serve a dual role in avoiding and in countering photooxidative stress, and that the relative significance of these two functions is dependent on the severity of droughtinduced light excess. For this purpose, we conducted a observational field study on Phillyrea latifolia, a Mediterranean evergreen sclerophyllous shrub that displays a strict anisohydric (and water spending) behavior to cope with drought [3]. P. latifolia represents an interesting species to elucidate the putative dual photoprotective function of phenylpropanoids, since it possesses a wide array of structures, comprising monohydroxy- and dihydroxy-B-ring-substituted flavones and flavonols $[9,14,60]$. To test our hypothesis, we carried out both physiological analyses and quantification of individual photosynthetic and non-photosynthetic pigments during spring and summer and at different hours of the day. We also quantified, for the first time, the accumulation of major individual phenylpropanoids, namely caffeic acid and flavonoid derivatives [14,41,42], in different leaf tissue layers.

\section{Results}

\subsection{Effects of Season and Hour of the Day on Water Relations and Gas Exchange}

The physiological traits examined in our study varied considerably on a daily and particularly on a seasonal basis (Table 1, Figure 1). Leaf water potential $\left(\Psi_{\mathrm{W}}\right)$ significantly changed between seasons, with steep spring-to-summer reductions $(-85 \%)$, irrespective of the hour of the day (Figure 1a). Leaf $\Psi_{\mathrm{w}}$ also changed during the day, with substantial morning-to-midday declines ( $-58 \%$ on average), irrespective of the season. Relative water content (RWC) significantly declined from spring to summer $(-20 \%)$, and daily variations in RWC were more noticeable in summer leaves (Figure $1 b)$. Net photosynthesis $\left(A_{N}\right)$ decreased $(-32 \%)$ from spring to summer, irrespective of the hour of the day. In addition, in both seasons, $A_{N}$ declined from early morning to midday (on average $-23 \%$ ), especially in summer $(-30 \%)$, and fully recovered in the early afternoon (Figure 1c). Overall, summer leaves displayed a lower (on average $-35 \%$ ) capacity to use radiant energy for photosynthesis (iRUE, instantaneous radiation use efficiency, sensu Penuelas et al. [61]) compared with spring leaves (Figure 1d). Greater morning-to-midday reductions in iRUE were also observed in summer leaves ( $-65 \%$ versus $-45 \%$ of spring leaves).

\subsection{Effects of Season and Hour of the Day on Photosynthetic and Non-Photosynthetic Pigments}

The content of the photosynthetic pigments varied on a seasonal but also on a daily basis (Table 1, Figure 2). The concentration of chlorophyll $\left(\mathrm{Chl}_{\text {tot }}\right)$ decreased $(-11 \%)$ from spring to summer, and from early morning to midday hours, especially in spring leaves $\left(-10 \%\right.$; Figure 2a). However, the ratio of $\mathrm{Chl}_{\mathrm{a}}$ to $\mathrm{Chl}_{\mathrm{b}}\left(\mathrm{Chl}_{\mathrm{a}} / \mathrm{Chl}_{\mathrm{b}}\right)$ was higher in summer leaves than in spring ones, with a greater increase from morning to midday (Figure $2 \mathrm{~b}$ ). Similar to $\mathrm{Ch}_{\text {tot }}$, carotenoids $\left(\mathrm{Car}_{\text {tot }}\right)$ decreased from spring to summer $(-15 \%)$ and declined from morning to midday, especially in spring (Figure 2c). 
Table 1. Summary of the two-way analysis of variance (ANOVA; season and time of day as fixed factors, with their interaction factors) for the set of physiological (total degrees of freedom $=63$ ) and biochemical (total degrees of freedom $=47$ ) traits of Phillyrea latifolia leaves. In situ measurements and sampling were conducted in two seasons: spring (11-12 and 25-26 May) and summer (4-5 and 22-23 July) in 2019; at four different times of day (08:00-09:00; 12:00-13:00; 14:30-15:30 and 17:30-18:30 h). $\Psi_{\mathrm{W}}$, leaf water potential; RWC, relative water content; $\mathrm{A}_{\mathrm{N}}$, net photosynthesis; iRUE, instantaneous radiation use efficiency; $\mathrm{Chl}_{\text {tot }}$, total chlorophyll content; $\mathrm{Chl}_{\mathrm{a}} / \mathrm{Chl}_{\mathrm{b}}$, ratio of $\mathrm{Chl}_{\mathrm{a}}$ to $\mathrm{Ch}_{\mathrm{b}}$; Cartot, total carotenoid content; VAZ $\mathrm{Chl}_{\text {tot }}{ }^{-1}$, violaxanthin cycle pigments relative to total chlorophyll concentration; DES, de-epoxidation state of violaxanthin cycle pigments, calculated as $(0.5 \mathrm{~A}+\mathrm{Z})(\mathrm{VAZ})^{-1} ; \mathrm{HCA}_{\text {tot }}$, total hydroxycinnamic (mostly caffeic acid) derivatives; Flav tot, total flavonoids; Que, quercetin; Lut, luteolin; Kae, Kampferol; Api, apigenin. ${ }^{* * *} p<0.0001 ;{ }^{* * *} p<0.001{ }^{* *} p<0.01$; ${ }^{*} p<0.05$; n.s., not significant.

\begin{tabular}{|c|c|c|c|}
\hline Parameter & $F_{\text {season }}$ & $F_{\text {day time }}$ & $F_{\text {season } \times \text { hour }}$ \\
\hline$\Psi_{\mathrm{w}}(-\mathrm{MPa})$ & $2958.0^{* * * *}$ & $385.1^{* * * *}$ & $34.9^{* * * *}$ \\
\hline RWC $(\%)$ & $1324.5^{* * * *}$ & $325.6^{* * * *}$ & $147.1^{* * * *}$ \\
\hline $\mathrm{A}_{\mathrm{N}}\left(\mu \mathrm{mol} \mathrm{CO} \mathrm{CO}^{-2} \mathrm{~s}^{-1}\right)$ & $240.8^{* * * *}$ & $23.9^{* * * *}$ & $6.5 *$ \\
\hline iRUE ( $\mu \mathrm{mol} \mathrm{CO} \mathrm{mmol}^{-1}$ quanta) & $458.6^{* * * *}$ & $425.1^{* * * *}$ & 2.0 n.s. \\
\hline $\mathrm{Chl}_{\mathrm{tot}}\left(\mu \mathrm{mol} \mathrm{g}{ }^{-1} \mathrm{DW}\right)$ & $41.1^{* * * *}$ & $55.1^{* * * *}$ & $27.8^{* * * *}$ \\
\hline $\mathrm{Chl}_{\mathrm{a}} / \mathrm{Chl}_{\mathrm{b}}$ & $212.6^{* * * *}$ & $154.2^{* * * *}$ & $78.9^{* * * *}$ \\
\hline $\operatorname{Car}_{\text {tot }}\left(\mu \mathrm{mol} \mathrm{g}{ }^{-1} \mathrm{DW}\right)$ & $54.1^{* * * *}$ & $13.2^{* * *}$ & $8.6^{* *}$ \\
\hline Neoxanthin $\left(\mathrm{mmol} \mathrm{mol}^{-1} \mathrm{Chl}_{\mathrm{tot}}\right)$ & 1.8 n.s. & 2.4 n.s. & 0.9 n.s. \\
\hline Violaxanthin $\left(\mathrm{V}, \mathrm{mmol} \mathrm{mol}{ }^{-1} \mathrm{Chl}_{\mathrm{tot}}\right)$ & $6.2 *$ & $256.8^{* * * *}$ & $9.3^{* *}$ \\
\hline Antheraxanthin $\left(\mathrm{A}, \mathrm{mmol} \mathrm{mol}^{-1} \mathrm{Chl}_{\mathrm{tot}}\right)$ & $76.9^{* * * *}$ & $285.4^{* * * *}$ & $14.8^{* * *}$ \\
\hline Zeaxanthin $\left(\mathrm{Z}, \mathrm{mmol} \mathrm{mol}^{-1} \mathrm{Chl}_{\mathrm{tot}}\right)$ & $455.6^{* * * *}$ & $956.0^{* * * *}$ & $64.7^{* * * *}$ \\
\hline Lutein $\left(\mathrm{mmol} \mathrm{mol}^{-1} \mathrm{Chl}_{\mathrm{tot}}\right)$ & $9.1^{* *}$ & $5.4 *$ & 2.6 n.s. \\
\hline B-carotene $\left(\mathrm{mmol} \mathrm{mol}^{-1} \mathrm{Chl}_{\mathrm{tot}}\right)$ & 2.9 n.s. & $16.3^{* *}$ & $4.3 *$ \\
\hline $\mathrm{VAZChl} \mathrm{tot}^{-1}\left(\mathrm{mmol} \mathrm{mol}^{-1}\right)$ & $165.4^{* * * *}$ & $38.2^{* * * *}$ & 1.5 n.s. \\
\hline DES & $292.6^{* * * *}$ & $335.1^{* * * *}$ & $25.4^{* * * *}$ \\
\hline $\mathrm{HCA}_{\text {tot }}\left(\mu \mathrm{mol} \mathrm{g}{ }^{-1} \mathrm{DW}\right)$ & $435.6^{* * * *}$ & $84.7^{* * * *}$ & $11.5^{* *}$ \\
\hline Flav $_{\text {tot }}\left(\mu \mathrm{mol} \mathrm{g}{ }^{-1} \mathrm{DW}\right)$ & $3953.1 * * * *$ & $199.7^{* * * *}$ & $64.2^{* * * *}$ \\
\hline Que 3-O-der ( $\left.\mu \mathrm{mol} \mathrm{g}^{-1} \mathrm{DW}\right)$ & $3176.3^{* * *}$ & $175.4^{* * * *}$ & $89.1^{* * * *}$ \\
\hline Lut $7-O-d e r\left(\mu \mathrm{mol} \mathrm{g}{ }^{-1} \mathrm{DW}\right)$ & $1412.6^{* * * *}$ & $58.6^{* * * *}$ & $12.7^{* *}$ \\
\hline Lut $4^{\prime}-O-\operatorname{der}\left(\mu \mathrm{mol} \mathrm{g}{ }^{-1} \mathrm{DW}\right)$ & $19.3^{* * *}$ & $12.1^{* *}$ & 2.4 n.s. \\
\hline Kae 3-O-der $\left(\mu \mathrm{mol} \mathrm{g}{ }^{-1} \mathrm{DW}\right)$ & $6.8 *$ & 1.4 n.s. & 1.1 n.s. \\
\hline Api 7-O-der $\left(\mu \mathrm{mol} \mathrm{g}{ }^{-1} \mathrm{DW}\right)$ & $5.2 *$ & 1.1 n.s. & 0.8 n.s. \\
\hline
\end{tabular}

Neoxanthin (data not shown), lutein and B-carotene changed slightly on both a seasonal and a daily basis (Table 1), although $\mathrm{B}$-carotene showed significant reductions from early morning to afternoon (12 and $15 \mathrm{~h}$ ) both in spring and summer leaves (Figure $3 \mathrm{a}, \mathrm{b}$ ). Conversely, violaxanthin cycle pigment relative to the total chlorophyll concentration $\left(\mathrm{VAZ} \mathrm{Chl} \mathrm{tot}^{-1}\right.$ ) greatly changed depending both on the season and the hour of the day (Figure 3c,d, purple lines). The daily changes in both VAZ $\mathrm{Chl}_{\text {tot }}{ }^{-1}$ and the de-epoxidation state (DES) of VAZ showed different trends in spring and summer leaves, with the values of both parameters being higher in summer (Figure $3 c, d$ ). When individually evaluated, it was observed that the concentration of violaxanthin $(\mathrm{V})$ did not change much, whereas antheraxanthin (A) and particularly zeaxanthin (Z) concentrations increased markedly from spring to summer, especially in the afternoon (Figure $3 \mathrm{e}, \mathrm{f}$ ). Violaxanthin and zeaxanthin displayed a reverse daily trend in spring leaves (Figure 3e). In particular, the $Z$ content increased from early morning to noon, followed by a decline in the early and late afternoon. However, in summer, the sharp morning-to-midday increase in $\mathrm{Z}$ was not completely matched by a parallel decrease in $\mathrm{V}$ content (Figure 3e,f). In addition, $\mathrm{Z}$ did not decline from midday to early afternoon (Figure $3 \mathrm{f}$ ). 

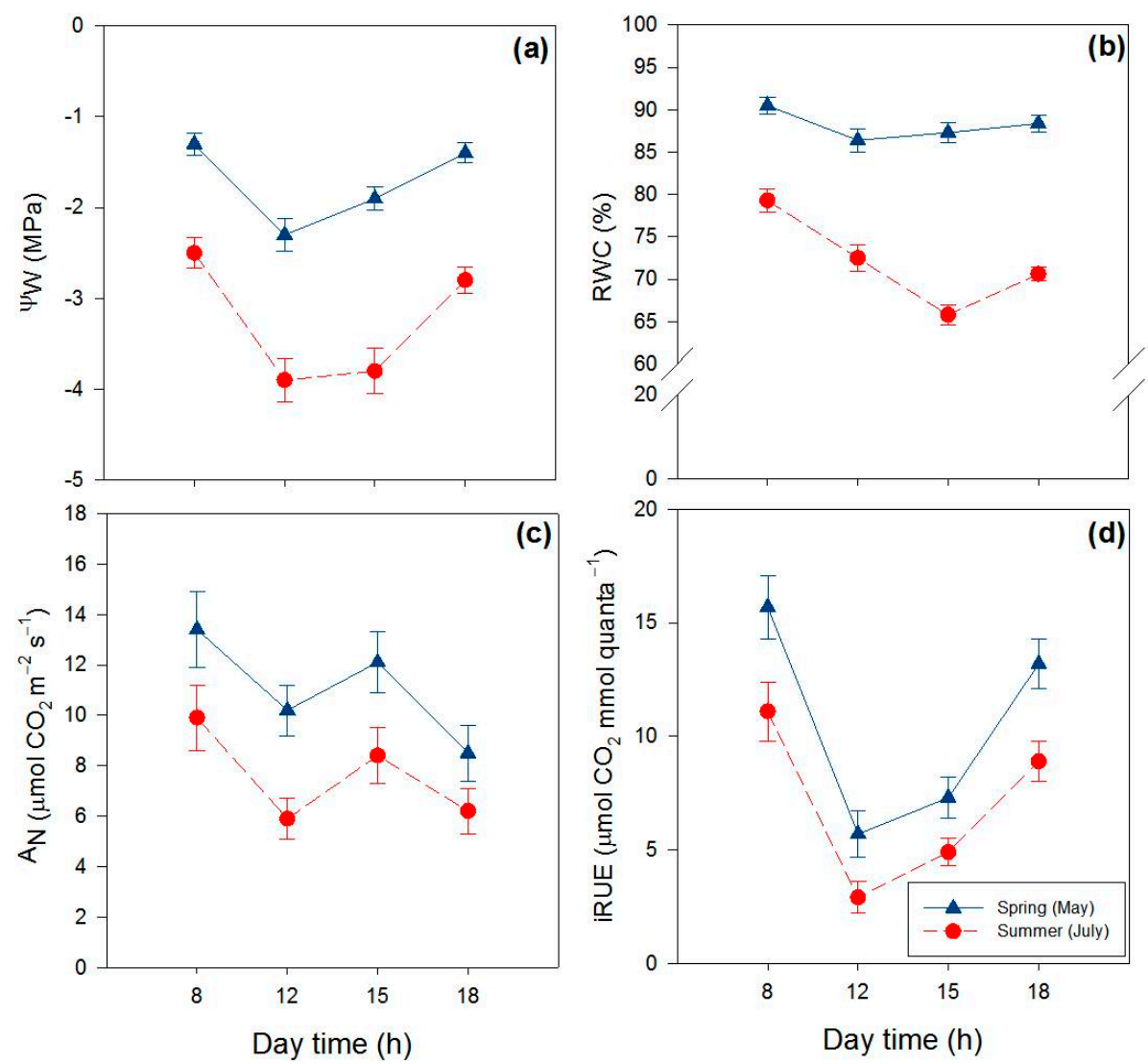

Figure 1. Seasonal and daily variations in leaf water potential $\left(\psi_{\mathrm{W}},(\mathbf{a})\right)$, relative water content (RWC, (b)), net $\mathrm{CO}_{2}$ assimilation rate $\left(\mathrm{A}_{\mathrm{N}},(\mathbf{c})\right)$ and instantaneous radiation use efficiency (iRUE, (d)) in P. latifolia leaves. Measurements were conducted at 08:00-09:00 (8 h in the graphs), 12:00-13:00 (12 h), 14:30-15:30 (15 h) and 17:30-18:30 (18 h) hours at two dates in spring (11-12 and 25-26 May, blue lines) and summer (4-5 and 22-23 July, red dashed lines) on clear days. Data are reported as means \pm SD $(n=8)$.
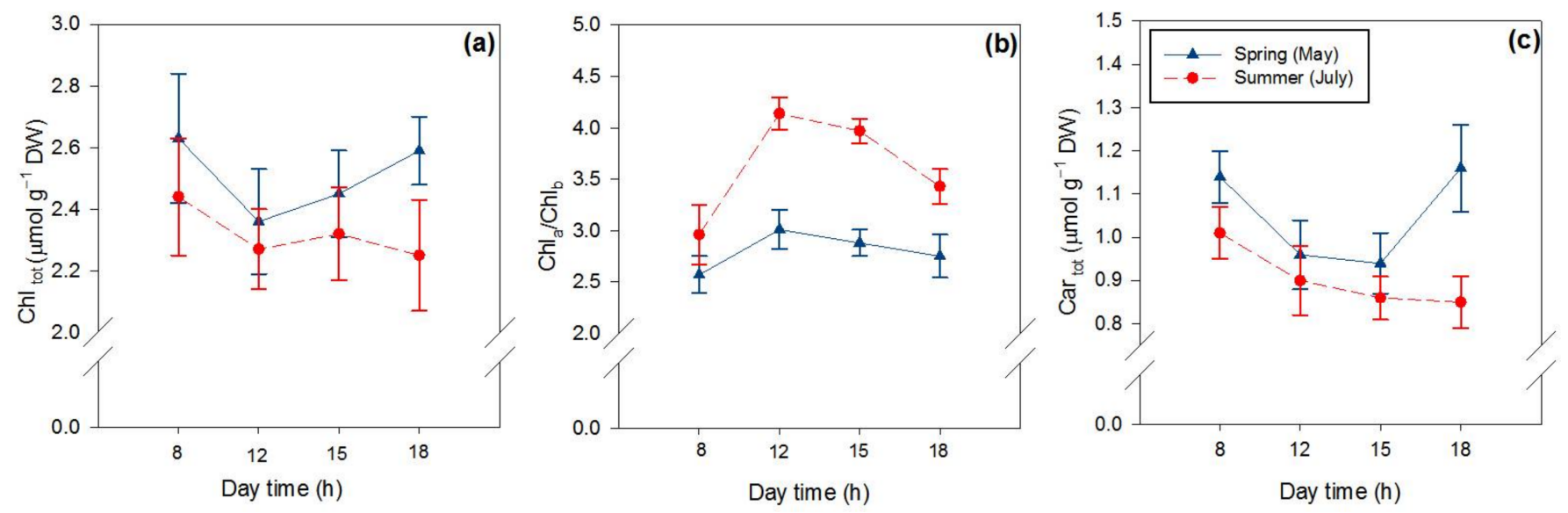

Figure 2. Seasonal and daily variations in total chlorophyll $\left(\mathrm{Chl}_{\text {tot }},(\mathbf{a})\right)$, the ratio of $\mathrm{Chl}_{\mathrm{a}}$ to $\mathrm{Chl}_{\mathrm{b}}\left(\mathrm{Chl}_{\mathrm{a}} / \mathrm{Chl}_{\mathrm{b}}\right.$, $\left.(\mathbf{b})\right)$ and total carotenoids (Car tot $(\mathbf{c})$ ) in the leaves of P. latifolia. Leaves were sampled at 08:00-09:00 (8 h in the graphs), 12:00-13:00 (12 h), 14:30-15:30 (15 h) and 17:30-18:30 (18 h) hours at two dates in spring (11-12 and 25-26 May, blue lines) and summer (4-5 and 22-23 July, red dashed lines) on clear days. Data are reported as means $\pm \operatorname{SD}(n=6)$. 

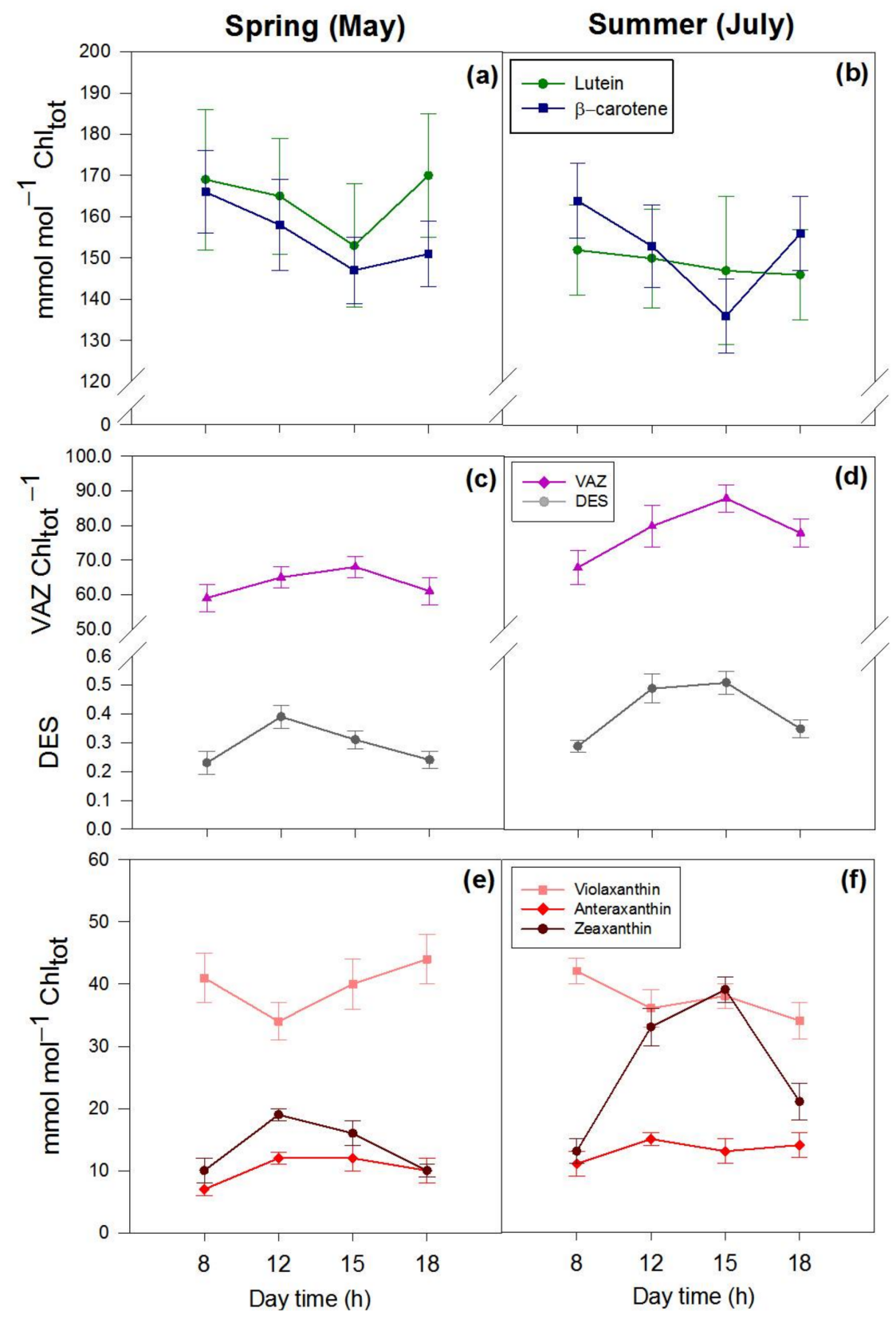

Figure 3. Daily variations in the content of individual carotenoids $\left(\mathrm{mmol} \mathrm{mol}^{-1} \mathrm{Chl}_{\text {tot }}\right)$ in spring $((\mathbf{a}, \mathbf{c}, \mathbf{e})$-left $)$ and summer $((\mathbf{b}, \mathbf{d}, \mathbf{f})$-right) leaves of $P$. latifolia. (a,b) Content of $\mathbf{B}$-carotene and lutein; (c,d) ratio of violaxanthin cycle pigments (VAZ) relative to total chlorophyll concentration $\left(\mathrm{VAZ} \mathrm{Chl}_{\mathrm{tot}^{-1}}{ }^{-1}\right)$ and the de-epoxidation state of VAZ $(\mathrm{DES}=((0.5 \mathrm{~A}+\mathrm{V})(\mathrm{VAZ})-1) .(\mathbf{e}, \mathbf{f})$ Content of violaxanthin cycle pigments (violaxanthin, anteraxanthin and zeaxanthin). Leaves were sampled at 08:00-09:00 ( $8 \mathrm{~h}$ in the graphs), 12:00-13:00 (12 h), 14:30-15:30 (15 h) and 17:30-18:30 (18 h) hours ontwo dates in spring (11-12 and 25-26 May) and summer (4-5 and 22-23 July) on clear days. Data are reported as means $\pm \mathrm{SD}(n=6)$.

The variation in the content of hydroxycinnamic acid derivatives $\left(\mathrm{HCA}_{\mathrm{tot}}\right.$, mostly consisting of echinacoside and verbascoside) and flavonoids (Flav tot) was remarkable on botha seasonal and a daily basis (Figure $4 a, b$, Table 1 ). The spring-to-summer increase in the flavonoid content $(+189 \%)$ was mostly due to the increment in quercetin-3-O- $(+415 \%)$ and luteolin-7-O-derivatives $(+218 \%)$, and to the increase in luteolin- $4^{\prime}-O$-derivatives $(+61 \%)$, to a minor extent (Figure $4 \mathrm{c}-\mathrm{f}$, Table 1). The content of kaempferol and apigenin derivatives, which correspond to approx. $1.0 \%$ of the Flav $v_{\text {tot }}$, slightly varied both seasonally and daily (Table 1, Figure 4c,d, pink lines). Interestingly, the quercetin-3-O- and luteolin-7-O- 
derivatives contents showed large morning-to-midday increases (Table 1, Figure 4c,d, black lines; Figure 4e,f, light blue lines). As also observed for $\mathrm{Z}$, the contents of quercetin-3-O and luteolin-7-O-derivatives did not decline from midday to early afternoon in summer leaves (Figure $4 \mathrm{~d}, \mathrm{f}$ ), whereas they significantly declined over the same time interval in spring leaves (Figure 4c,e).
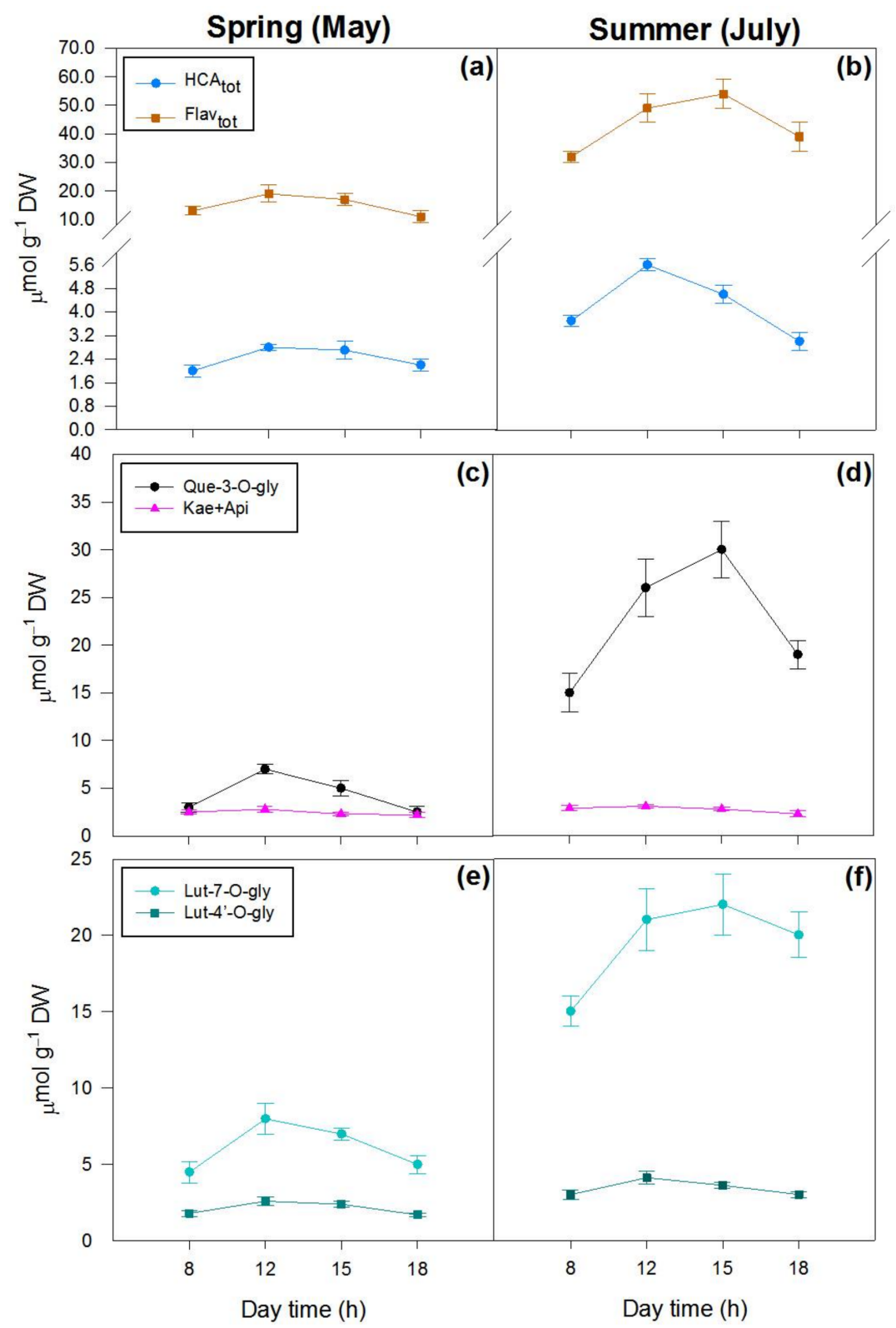

Figure 4. Daily variations in the content ( $\left.\mu \mathrm{mol} \mathrm{g}^{-1} \mathrm{DW}\right)$ of phenylpropanoids in spring $((\mathbf{a}, \mathbf{c}, \mathbf{e})-$ left $)$ and summer $\left((\mathbf{b}, \mathbf{d}, \mathbf{f})-\right.$ right) leaves of P. latifolia. $(\mathbf{a}, \mathbf{b})$ Content of hydroxycinnamates $\left(\mathrm{HCA}_{\text {tot }}\right)$ and flavonoids $\left(\right.$ Flav $\left._{\text {tot }}\right) ;(\mathbf{c}, \mathbf{d})$ content of quercetin-3-O-glycosides and kaempferol + apigenin derivatives; $(\mathbf{e}, \mathbf{f})$ content of luteolin-7-O- and luteolin- $4^{\prime}-\mathrm{O}$-glycosides. Measurements were conducted at 08:00-09:00 ( $8 \mathrm{~h}$ in graph), 12:00-13:00 (12 h), 14:30-15:30 (15 h) and 17:30-18:30 (18 h) hoursontwo dates in spring (11-12 and 25-26 May) and summer (4-5 and 22-23 July) on clear days. Data are reported as means $\pm \mathrm{SD}(n=6)$.

\subsection{Tissue Distribution of Hydroxycinnamic Acid Derivatives and Flavonoids in Spring and Summer Leaves}

The HPLC-DAD analysis showed that the general phenylpropanoid profile was similar among the different leaf tissues (adaxial and abaxial epidermis, and the adaxial, inner 
and abaxial mesophyll), with 13 peaks being detected and identified as follows: 1, quercetin derivative; 2, luteolin-7-O-Glc derivative; 3, quercetin derivative; 4, luteolin-7-O-Glc derivative; 5 , hydroxycinnamic acid derivative; 6 , kaempferol derivative; 7 , apigenin derivative; 8 , hydroxycinnamic acid derivative; 9 , hydroxycinnamic acid derivative; 10 , apigenin derivative; 11 , apigenin derivative; 12 , luteolin-4'-O-Glc derivative; 13 , luteolin-7-O-Glc derivative (Figure 5). However, despite being similar in composition, the concentrations of these phenylpropanoids proved to be different in each leaf tissue (Figures 5 and 6). In addition, the content of these compounds greatly differed between seasons, being higher in summer (Figure 6).

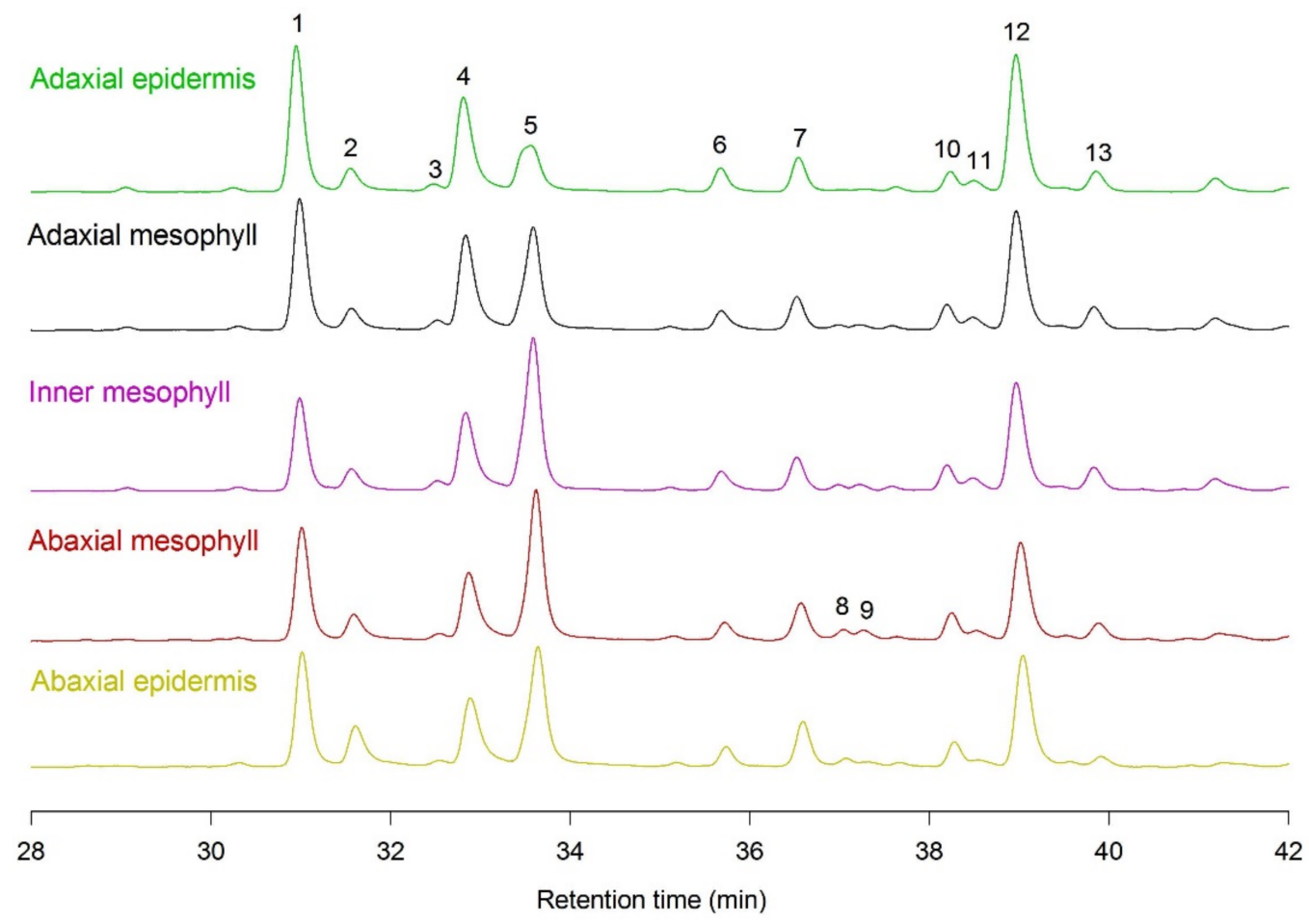

Figure 5. Representative chromatograms (at $310 \mathrm{~nm}$ ) showing the phenylpropanoid profile of individual tissues (adaxial epidermis—green; adaxial mesophyll—black; inner mesophyll—purple; abaxial mesophyll—red; abaxial epidermis-yellow) of $P$. latifolia leaves sampled during the central hours of the day in summer (22-23 July). Cross-sections were preliminarily observed under light to determine the thickness of the adaxial epidermis, the mesophyll parenchyma (palisade and spongy) and the abaxial epidermis. The analyses were conducted on longitudinal $25 \mathrm{~mm}^{2}$ leaf sections, obtained by cryostat sectioning from two replicate specimens, each one consisting of 4-5 leaves. Different leaftissue layers were obtained by cutting pieces at $40 \mu \mathrm{m}$ depth from the upper surface (adaxial epidermis), then down in three $120 \mu \mathrm{m}$ steps, to obtain the adaxial, inner and abaxial mesophyll, respectively. The remaining tissue consisted almost exclusively of the abaxial epidermis.

Epidermal flavonoids corresponded to $30 \%$ and $20 \%$ of the whole-leaf flavonoid content in spring and summer leaves, respectively (Figure 6a,e). This is consistent with the observation that the mesophyll flavonoids increased to greater extent $(+138 \%$, Figure $6 \mathrm{~b}-\mathrm{d})$ compared with the epidermal ones $(+55 \%$, Figure $6 \mathrm{a}, \mathrm{e})$ from spring to summer. While the different flavonoids accumulated in the adaxial epidermis almost uniformly, irrespective of the season (Figure 6a), quercetin-3-O- and luteolin-7-O-derivatives (gray and orange bars, respectively) mostly accumulated in the mesophyll cells (contributing an average of $63 \%$ of the whole-leaf flavonoid pool), particularly in summer leaves (69\%, right panels). Luteolin$4^{\prime}$-O-derivatives (yellow bars) contributed more substantially to the total flavonoids in the adaxial epidermis (23\%, Figure 6a), but much less in other leaf tissues ( $15 \%$ of Flav tot of the mesophyll (Figure $6 \mathrm{~b}-\mathrm{d}$ ) and $12 \%$ of the abaxial epidermis (Figure 6e). Kaempferol and apigenin derivatives (pink bars) mostly occurred in the adaxial epidermis ( $20 \%$ of 
whole-leaf Flav tot, Figure 6a), also with a large content (14\%) in abaxial epidermal cells (Figure 6e). These compounds were present at very low concentrations in the mesophyll tissues ( $5 \%$ of whole-leaf Flav ${ }_{\text {tot }}$, Figure $6 \mathrm{~b}-\mathrm{d}$ ). Finally, caffeic acid derivatives (HCA, blue bars) accumulated poorly in adaxial tissues (Figure $6 a, b$ ), whereas they were the predominant phenylpropanoids detected in the abaxial epidermis in comparison with the other phenylpropanoids (Figure 6e).

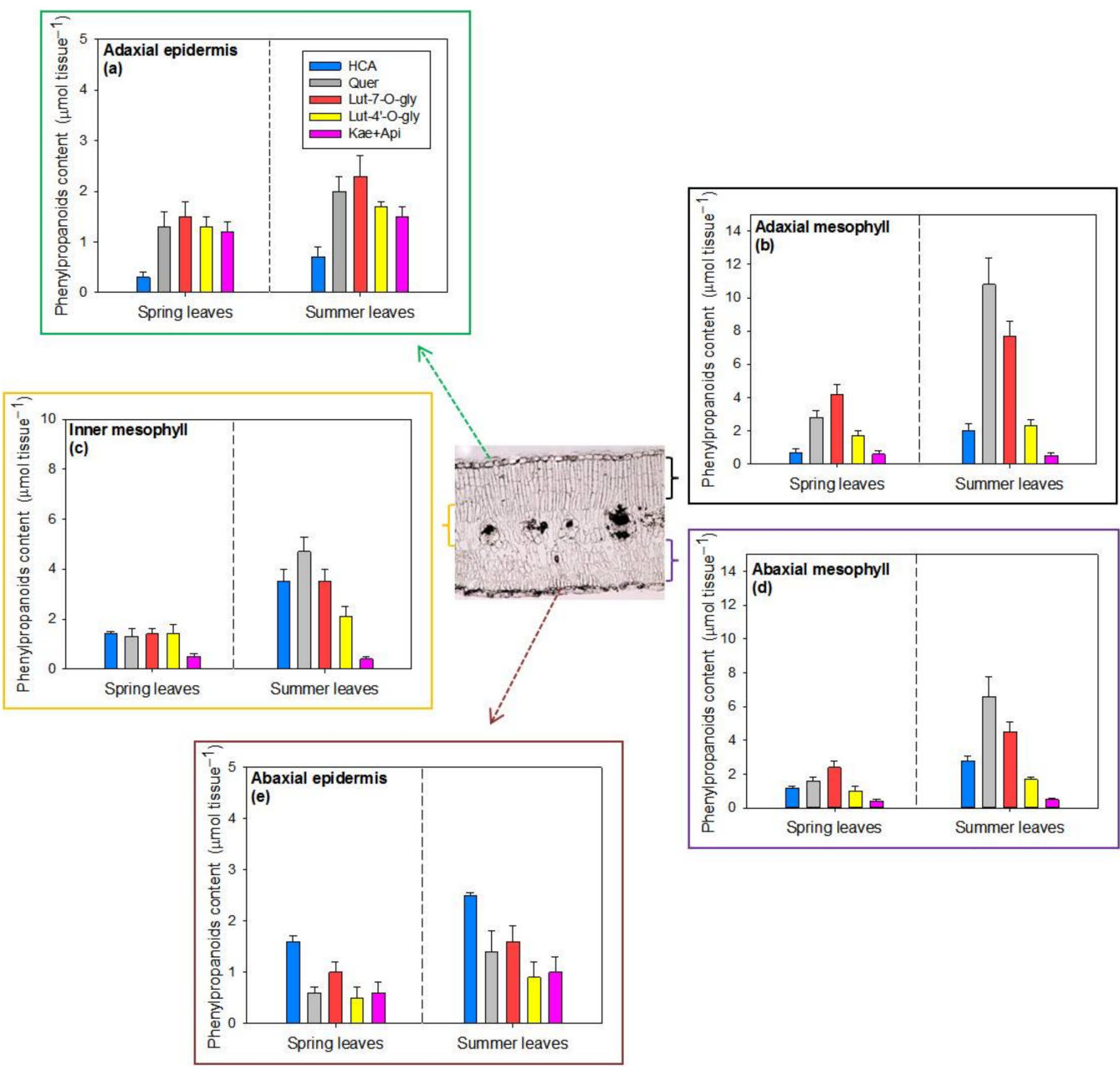

Figure 6. Content of phenylpropanoids $\left(\mu \mathrm{mol}\right.$ tissue ${ }^{-1}$ ) in different tissues (different colored rectangles: (a), adaxial epidermis; (b), adaxial mesophyll; (c), inner mesophyll; (d), abaxial mesophyll; (e), abaxial epidermis) of spring (left-hand bars) and summer (right-hand bars) leaves of $P$. latifolia. Leaves were sampled during the central hours of the day (12:00-14:00 h) in spring (10-11 and 25-26 May) and summer (4-5 and 22-23 July). Analyses were conducted on two replicates for each sampling date, each replicate consisting of $4-5$ leaves. The concentration of metabolites ( $\mu \mathrm{mol} \mathrm{g}^{-1}$ DW) was multiplied by the DW of each tissue layer to calculate the tissue phenylpropanoid content $\left(\mu \mathrm{mol} \mathrm{tissue}^{-1}\right)$. Data are reported as means $\pm \mathrm{SD}(n=4)$.

\section{Discussion}

The data of our study show that $P$. latifolia suffered from water stress not only seasonally but also on a daily basis. Declines in both leaf $\Psi_{\mathrm{W}}$ and RWC from early morning to midday resulted in significant reductions in net assimilation rates and, consequently, in even greater declines in instantaneous radiation use efficiency. This was particularly evident during summer, when plants suffered from the combined action of soil water deficit and high temperatures. In other words, P. latifolia leaves suffered from excess light stress during the central hours of the day, and the severity of this increased from spring to summer. Here, we reason how seasonal and daily changes in the concentration and 
composition of photosynthetic and non-photosynthetic pigments may allow P. latifolia leaves to avoid irreversible photodamage and hence to cope successfully with multiple environmental pressures associated with the Mediterranean climate.

Firstly, we observed that chlorophylls declined from spring to summer and from early morning to midday, thereby reducing the light absorption centers. This may have an adaptive value for plants facing high solar radiation under warm and dry climates. [62]. In addition, the higher $(+29 \%) \mathrm{Chl}_{\mathrm{a}} / \mathrm{Chl}_{\mathrm{b}}$ ratios observed in summer leaves, particularly during the central hours of the day $(+37 \%)$, may also have an adaptive value under high light stress conditions on both short- and long-term bases. In fact, higher $\mathrm{Chl}_{\mathrm{a}} / \mathrm{Ch}_{\mathrm{b}}$ ratios increased the proportion of reaction to light-absorbing centers [16,63,64].

Secondly, the data of our study pointed out the key photoprotective role of carotenoids not only on a daily but also on a seasonal basis. In detail, our findings strongly suggested an antioxidant role of carotenoids in leaves suffering from the most severe drought stress. In particular, we observed that VAZ $\mathrm{Chl}_{\text {tot }}{ }^{-1}$ exceeded $50 \mathrm{mmol} \mathrm{mol}^{-1}$. These values are consistent with those of plants growing under full sunlight over the entire growing season observed in previous studies $[16,25,26,51,65,66]$. This implies that a fraction of VAZ was probably not bound to the light-harvesting chlorophyll-protein complexes and hence was residing in other parts of the thylakoids [25-29]. This unbound pool of VAZ increased greatly during the central hours of the day in summer leaves, mostly due to the enhanced biosynthesis of zeaxanthin (Z). Summer leaves suffered from the severe reduction in iRUE induced by drought stress, being exposed to severe photooxidative stress during the central hours of the day. In addition, the morning-to-midday increase in $\mathrm{Z}$ concentration ( $25 \mathrm{mmmol} \mathrm{mol}^{-1} \mathrm{Chl}_{\text {tot }}$ on average) was not matched by a parallel decrease $\left(6 \mathrm{mmol} \mathrm{mol}^{-1} \mathrm{Chl}_{\text {tot }}\right.$ on average) in violaxanthin (V) concentration but it was parallel to the decrease in $B$-carotene content. We argue that a fraction of the $Z$ synthesized from morning to midday was likely through the hydroxylation of $ß$-carotene [31-33], and hence it was not involved in non-photochemical quenching. However, we cannot exclude that the decrease in B-carotene contents may have partially resulted from its oxidation by singlet oxygen [22]. Zeaxanthin behaves as a chloroplast antioxidant (sensu Halliwell and Gutteridge [67] and Havaux and Garcia-Plazaola [68]), primarily due to its ability to confer rigidity to the thylakoid membranes [68-70] but also due to its capacity to quench singlet oxygen [71,72]. In our study, this may have well limited lipid membrane peroxidation and preserved chloroplasts from irreversible photooxidative damage in summer leaves, when drought stress became particularly severe.

Finally, our study offers novel evidence of the daily and seasonal changes in the biosynthesis of individual flavonoids, as well as of their tissue-specific distribution. The large plasticity in flavonoid biosynthesis observed in both the short- and long-term, as well as in the different leaf tissues, poses new questions that need attention, as outlined below.

The finding of the enhanced biosynthesis of flavonoids from spring to summer, when drought stress increased because of reduced precipitation, is consistent with previous studies $[38,51,52,73,74]$ and is possibly related to the evergreen habit of $P$. latifolia [75]. Indeed, the high flavonoid content in summer may equip the severely drought-stressed evergreen leaves with an effective photoprotective arsenal to cope with the excess light. In fact, our study offers novel evidence that the spring-to-summer increment in flavonoid content $\left(\sim 32 \mu \mathrm{mol} \mathrm{g}{ }^{-1} \mathrm{DW}\right)$ almost exclusively involved 3-O-quercetin $\left(18.5 \mu \mathrm{mol} \mathrm{g}{ }^{-1}\right.$ DW) and 7-O-luteolin $\left(11.5 \mu \mathrm{mol} \mathrm{g}^{-1} \mathrm{DW}\right)$ derivatives. This led us to hypothesize that these flavonoids, besides having limited the entry of shortwave solar radiation, might also have scavenged the ROS generated by the decreased use of photosynthetic active radiation for photosynthesis due to the severe drought $[38,40,76,77]$. The finding that the spring-to-summer increases in the content of quercetin and luteolin glycosides mostly regarded the mesophyll tissues adds further support to our idea. Indeed, there is relatively old evidence that dihydroxy B-ring-substituted flavonoids are located not only in the vacuole but also in the chloroplasts of the mesophyll cells in P. latifolia adapted to full solar irradiance. Therefore, these compounds would be capable of scavenging $\mathrm{H}_{2} \mathrm{O}_{2}$ and 
singlet oxygen $[14,38,41,78]$. In agreement with our findings, Csepregi et al. [58] recently observed a smaller ratio of epidermal flavonoids to those located in the rest of the leaf of Vitis vinifera plants growing under non-irrigated field conditions. They suggest that these phenolics, especially quercetin derivatives, acted mostly as ROS scavengers rather than as UV attenuators [58].

The large fluctuation in the content of dihydroxy B-ring-substituted flavonoids on a diurnal basis is intriguing but, at the same time, poses questions that merit deep attention. Dawn-to-midday enhancements in flavonoid amounts, particularly in Que-3-O-glucoside, have been previously observed by Barnes et al. [57]. However, in our study, these morningto-midday increases in the whole-leaf flavonoid content were strong, especially during the summer period. We surmise that this was the result of the concomitant action of multiple environmental stressors during this season and in the daytime, such as high light irradiance, elevated air temperatures and water deficit. All these stressors could enhance the biosynthesis of flavonoids, likely through ROS/redox modulation of the transcription factors involved in regulating flavonoid biosynthesis [79-82]. Indeed, as reported above, leaves suffered from severe light excess during the central hours of the day (on average, iRUE decreased by $65 \%$ ), particularly in summer $(-70 \%)$, and the consequent transient increase in ROS generation may have triggered the biosynthesis of flavonoids with an effective antioxidant capacity $[83,84]$. In fact, $\mathrm{H}_{2} \mathrm{O}_{2}$, one of the major species of ROS, has been proposed as a conductor of the daily changes in leaf antioxidant defense, acting as a messenger molecule [58]. Thus, the sharp enhancement in quercetin and luteolin derivatives from the early morning to the central hours of the day may have functional antioxidant significance, especially considering that the activities of the key antioxidant enzymes might have substantially declined with the severity of drought, as already reported in a range of species $[85,86]$. In our study, summer leaves were severely dehydrated at midday (RWC was $68 \%$ on average). As such, the leaf temperature (T) may have greatly exceeded that of the air $\left(32.4{ }^{\circ} \mathrm{C}\right.$ on average) because of stomatal constraints. This, in turn, may have led to enzyme inactivation [87-89], as already reported for the diurnal variations in antioxidant enzyme activity in drought-stressed Platanus $\times$ acerifolia and Fagus sylvatica plants $[25,88]$. Therefore, the mesophyll-located flavonoids, especially quercetin-3-O- and luteolin-7-O-glucosides, may have complemented the activity of the antioxidant enzymes to avoid irreversible photodamage during the hottest hours of the day $[25,90]$.

Additionally, it is interesting to note that despite having a luteolin aglycone, the luteolin-4'-O-derivatives showed a completely distinct diurnal and seasonal pattern, as well as a peculiar localization, when compared with those with the same aglycone but with -7-O-glycolization. Lut-4'-O-gly showed low diurnal and even seasonal variations (the opposite of Lut-7-O-gly derivatives) and contributed more substantially to the total flavonoids in the adaxial epidermis. These results support our hypothesis, since due to its substitution pattern with the sugar being linked to one of the catechol hydroxyls, this flavonoid should contribute less as an antioxidant in the mesophyll cells during the stress period.

The high daily turnover of quercetin and luteolin derivatives observed here poses the question whether the flavonoids have been degraded because of the combined action of high light and elevated leaf T [91] or have instead been oxidized by the excess of ROS (or through electron donation to vacuolar peroxidase)and not fully recycled to their reduced forms $[77,92,93]$. Addressing this complex issue requires further investigations aimed at exploring changes in both the sub-cellular distribution of ascorbate (and glutathione as well) [94,95] and the activity of mono-dehydroascorbate [93] in leaves facing severe drought stress.

The photoprotective roles of monohydroxy B-ring-substituted flavones and flavonols, and of caffeic acid derivatives (HCA), are apparently of minor significance. As noted by Gould [96] and by Agati and Tattini [17], monohydroxy B-ring-substituted flavonoids may be constitutive effective shields against UV radiation, whereas HCAs are mostly 
devoted to absorbing wavelengths over the UV-B portion. This is of high adaptive value against severe solar radiation. The preferential accumulation of HCA in the inner and abaxial mesophyll and in the abaxial epidermis is not surprising. The location of these compounds is consistent with the notion of strong competition between the early and late branch pathways of the general phenylpropanoid metabolism $[97,98]$, with the flavonoid metabolism being favored under the most severe photooxidative stress conditions [90]. We surmise that the preferential accumulation of flavonoids, especially on the adaxial side, might be also related to the adaxial localization of the palisade parenchyma on dorsiventral leaves, which has a denser occurrence of chloroplasts, structures which are greatly exposed to the imbalance of ROS production and ROS scavenging [99].

Finally, we are aware that our analysis of phenylpropanoids targeted to just caffeic acid and flavonoid derivatives might have underestimated the functional roles of other minor phenolics in the responses of P. latifolia to drought stress of increasing severity. On the other hand, it has long been known that under the severe light excess imposed by the combined action of high solar irradiance and water deficit, carbon skeletons and energy are almost exclusively devoted to the biosynthesis of flavonoids, particularly flavonols $[9,14,17,37,41,42,97]$. Nonetheless, a complete analysis of the huge number of phenolics present in leaf tissues merits future investigation using untargeted metabolomic tools.

In conclusion, our investigation offered compelling evidence of the prominent role of photosynthetic and non-photosynthetic pigments in protecting P. latifolia leaves against photodamage at both the diurnal and seasonal timescales, thus helping this plant to cope successfully with the environmental pressures associated with the Mediterranean climate.

\section{Materials and Methods}

\subsection{Plant Material and Growth Conditions}

The study was conducted on plants growing on seashore dunes at Grosseto (Tuscany, Italy), with in situ measurements and sampling conducted in 2 seasons: spring (11-12 and 25-26 May) and summer (4-5 and 22-23 July) in 2019. Physiological measurements and collection of biochemical samples were carried out at 4different hours of the day: at 08:00-09:00 (named here as $8 \mathrm{~h}$ ), 12:00-13:00 (named here as 12 h), 14:30-15:30 (named here as $15 \mathrm{~h}$ ) and 17:30-18:30 (named here as $18 \mathrm{~h}$ ) hours. Meteorological data were recorded at the weather station of the Institute of Biometeorology of the National Research Council of Italy, located $15 \mathrm{~km}$ away from the experimental site. Average $\mathrm{min} / \mathrm{max}$ air temperatures (T) in May were $10.7 / 21.9^{\circ} \mathrm{C}$ and the cumulative precipitation was $100 \mathrm{~mm}$; the average $\mathrm{min} /$ max temperatures of $14.5 / 28.8^{\circ} \mathrm{C}$ were recorded in June with no precipitation; in July, the average $\mathrm{min} / \max$ temperatures were $17.7 / 32.4{ }^{\circ} \mathrm{C}$, also with no prior precipitation measurements. Daily global irradiance was, on average, $24.2 \mathrm{MJ} \mathrm{m}^{-2}$ in May, $29.7 \mathrm{MJ} \mathrm{m}^{-2}$ in June and $31.7 \mathrm{MJ} \mathrm{m}^{-2}$ in July. All measurements and sampling were conducted on clear days.

\subsection{Water Relations and Gas Exchange Measurements}

Relative water content $(R W C)$ and leaf water potential $\left(\Psi_{\mathrm{w}}\right)$ were measured on fully developed leaves (details of the sample size and the experimental plan are reported in Section 4.4). In particular, for RWC determination, leaves were wrapped in parafilm and transferred to the laboratory in a fridge bag to measure leaf fresh weight (FW). They were then hydrated until saturation for $48 \mathrm{~h}$ in darkness to determine the turgid weight (TW). The dry weight (DW) of the leaves was obtained after drying them for $48 \mathrm{~h}$ at $80^{\circ} \mathrm{C}$. RWC was calculated as follows (Equation (1)):

$$
\text { RWC }(\%)=(F W-D W) /(T W-D W)
$$

Leaf water potential $\left(\Psi_{\mathrm{W}}\right)$ was measured using a Scholander-type pressure chamber (PMS Instruments, Corvallis, OR, USA). Gas exchange measurements were acquired using a LI-6400 portable photosynthesis system (Li-Cor, Lincoln, NE, USA) equipped with a 
cuvette of $2 \mathrm{~cm}^{2}$, operating under ambient $\mathrm{CO}_{2}$ and environmental photosynthetic photon flux density. Photosynthesis $\left(A_{\mathrm{N}}\right)$ and instantaneous radiation use efficiency (iRUE) were calculated using the LI-6400 software.

\subsection{Analysis of Photosynthetic Pigments and Phenylpropanoids}

Individual carotenoids and chlorophylls were analyzed by extraction from fresh leaf material (approx. $400 \mathrm{mg}$ ) with $2 \times 4 \mathrm{~mL}$ of pure acetone (added to $0.8 \mathrm{~g} \mathrm{~L}^{-1}$ calcium carbonate). Aliquots $(15 \mu \mathrm{L})$ were injected into a Perkin Elmer Flexar liquid chromatograph equipped with a quaternary 200Q/410 pump and an LC 200 photodiode array detector (DAD) (all from Perkin Elmer, Bradford, CT, USA). The pigments were separated using a $250 \times 4.6 \mathrm{~mm}$ Zorbax SB-C18 $(5 \mu \mathrm{m})$ column (Agilent Italia, Milan, Italy), kept at $28{ }^{\circ} \mathrm{C}$. The column was eluted for $20 \mathrm{~min}$ with a linear gradient solvent system at a flow rate of $1.2 \mathrm{~mL} \mathrm{~min}^{-1}$, from $100 \% \mathrm{CH}_{3} \mathrm{CN} / \mathrm{MeOH}(95 / 5 \mathrm{v} / v$, with the addition of $0.05 \%$ triethylamine) to $100 \% \mathrm{MeOH} /$ ethyl acetate $(68 / 32 v / v)$. Individual pigments were identified through a comparison of their retention times and UVspectral features with those of authentic standards. Individual carotenoids and chlorophylls were quantified using the calibration curves of authenticated standards from Extrasynthese (Lyon-Nord, Genay, France) and Sigma Aldrich (Milan, Italy).

The whole-leaf concentration of the major phenylpropanoids was analyzed by extraction from fresh leaves $(250 \mathrm{mg}$ ) with $4 \times 4 \mathrm{~mL} 75 \% \mathrm{EtOH}$ ( $\mathrm{pH} 2.5$, achieved by $\mathrm{HCOOH}$ addition). The supernatant was partitioned with $4 \times 4 \mathrm{~mL}$ of $n$-hexane and reduced to dryness, and the residue was resuspended in $1 \mathrm{~mL} \mathrm{MeOH} / \mathrm{H}_{2} \mathrm{O}(90 / 10 v / v)$. Aliquots $(10 \mu \mathrm{L})$ were injected in the same HPLC-DAD equipment as reported above. Individual metabolites were separated using a $150 \times 4.6 \mathrm{~mm}$ ( $5 \mu \mathrm{m}$ particle size) Sun Fire column (Waters Italia, Milan, Italy), operating at $30^{\circ} \mathrm{C}$, at a flow rate of $1 \mathrm{~mL} \mathrm{~min}{ }^{-1}$. The mobile phases were: (A) Milli-Q $\mathrm{H}_{2} \mathrm{O}$ (pH 2.5, acidified by $\mathrm{H}_{3} \mathrm{PO}_{4}$ addition) $/ \mathrm{CH}_{3} \mathrm{CN}(90 / 10 v / v)$ and (B) Milli- $\mathrm{Q} \mathrm{H}_{2} \mathrm{O}$ (pH 2.5, acidified by $\mathrm{H}_{3} \mathrm{PO}_{4}$ addition) $/ \mathrm{CH}_{3} \mathrm{CN}(10 / 90 v / v)$, eluted in a linear gradient program from $100 \% \mathrm{~A}$ to $100 \% \mathrm{~B}$ during a $45 \mathrm{~min}$ run. The major phenylpropanoids were identified using the retention times and UV spectral characteristics of authentic standards (all from Extrasynthese, Lyon-Nord, Genay, France). Our analysis identified two derivatives of caffeic acids (echinacoside and verbascoside in the molar ratio of 15-20/80-85, irrespective of the season and hour of the day, referred as to HCA), and the glycosides of five flavonoid aglycones (quercetin, luteolin 7-O, luteolin 4'-O, kaempferol and apigenin). The content of the different phenylpropanoids is reported in $\mu \mathrm{mol} \mathrm{g}^{-1} \mathrm{DW}$.

Qualitative and quantitative analyses of caffeic acid and flavonoid derivativeswere also conducted in different tissues of leaves sampled during the central hours of the day (12.00-14:00 h) in both (25-26) May and (22-23) July, using the method of Alenius et al. [100]. Cross-sections were preliminarily observed under a light microscope (Zeiss Axio-Phot, Carl Zeiss, Jena, Germany) to determine the thickness of the adaxial epidermis, the mesophyll parenchyma (palisade and spongy) and the abaxial epidermis. The analyses were conducted on longitudinal $25 \mathrm{~mm}^{2}$ leaf sections, obtained by cryostatsectioning (Leica Cryocut 1800, Leica, Wetzlar, Germany, set at $-25^{\circ} \mathrm{C}$ ) from two replicate specimens for each sampling date, each one consisting of 4-5 leaves. Different leaf tissue layers were obtained by cutting pieces at $40 \mu \mathrm{m}$ depth from the upper surface (adaxial epidermis), then down in three $120 \mu \mathrm{m}$ steps to obtain the adaxial, inner and abaxial mesophyll, respectively (more details can be observed in Figure 6). The remaining tissue consisted almost exclusively of abaxial epidermis. The samples were immediately placed in a centrifuge tube containing $5 \mathrm{~mL}$ of $75 \% \mathrm{EtOH} / \mathrm{H}_{2} \mathrm{O}$ adjusted to $\mathrm{pH} 2.5$ with $\mathrm{HCOOH}$ (the phenylpropanoid extraction solution) and stored at $4{ }^{\circ} \mathrm{C}$ until the HPLC-DAD analysis, which was performed as reported above for the whole-leaf phenylpropanoids. The concentration of individual metabolites (in $\mu \mathrm{mol} \mathrm{g}^{-1} \mathrm{DW}$ ) was finally multiplied by the DW of each tissue layer to calculate the tissue's phenylpropanoid content (in $\mu \mathrm{mol}$ tissue ${ }^{-1}$ ). 


\subsection{Experimental Design and Statistical Analysis}

The experimental design was completely random, performed on eight individuals of P. latifolia selected from a group of 30 plants distributed over a $300 \mathrm{~m}^{2}$ area, $200 \mathrm{~m}$ away from the sea. Each plant was tagged, and fully developed leaves (from the fiftht or sixth nodes, counting from the shoot apex) were sampled for both physiological measurements and biochemical analyses. In particular, for each hour of the day, water relations and gas exchange were measured on two leaves per plant and combined to make an individual replicate $(n=8)$, whereas, for biochemical analyses, four leaves were pooled together from six different plants $(n=6)$. The content of individual phenylpropanoids in different leaf tissues was measured on four plants $(n=4)$, using the same leaves collected for the biochemical analyses at midday. Data were analyzed using a two-way ANOVA (SPSS v.20; IBM, Chicago, IL, USA), with season and hour of the day as factors, and considering their interaction (differences were considered significant at $p \leq 0.05$ ). The graphs were constructed using SigmaPlot Systatsoftware (v.12.5, SystatSoftware, Inc., San Jose, CA, USA).

Author Contributions: Conceptualization, M.T., A.G. and C.B.; methodology, L.B.d.S.N. and A.G.; software, L.B.d.S.N. and M.T.; validation, A.G., C.B. and M.T.; formal analysis, M.T., L.G., A.F.; investigation, A.G., C.B. and G.M.; resources, F.F. and M.C.; data curation, M.T. and L.B.d.S.N.; writing — original draft preparation, M.T.; writing — review and editing, all the authors; supervision, M.T., M.C. and F.F.; funding acquisition, M.C. and F.F. All authors have read and agreed to the published version of the manuscript.

Funding: This research was funded by the Italian MIUR to CNR project: "Economia Circolare" (Green and Circular Economy-GECE) (FOE-2019, 436 DBA.AD003.139).

Institutional Review Board Statement: Not applicable.

Informed Consent Statement: Not applicable.

Data Availability Statement: The data presented in this study are available on request from the corresponding author.

Conflicts of Interest: The authors declare no conflict of interest.

\section{References}

1. Tattini, M.; Loreto, F. Plants in Mediterranean areas: "Living in the sun". Environ. Exp. Bot. 2014, 103, 1-2. [CrossRef]

2. Fini, A.; Tattini, M.; Esteban, R. Plants' Responses to Novel Environmental Pressures. Front. Plant Sci. 2017, 8, 2000. [CrossRef] [PubMed]

3. Bussotti, F.; Ferrini, F.; Pollastrini, M.; Fini, A. The challenge of Mediterranean sclerophyllous vegetation under climate change: From acclimation to adaptation. Environ. Exp. Bot. 2014, 103, 80-98. [CrossRef]

4. Flexas, J.; Diaz-Espejo, A.; Gago, J.; Gallé, A.; Galmés, J.; Gulías, J.; Medrano, H. Photosynthetic limitations in Mediterranean plants: A review. Environ. Exp. Bot. 2014, 103, 12-23. [CrossRef]

5. Chaves, M.M.; Flexas, J.; Pinheiro, C. Photosynthesis under drought and salt stress: Regulation mechanisms from whole plant to cell. Ann. Bot. 2009, 103, 551-560. [CrossRef] [PubMed]

6. Matesanz, S.; Valladares, F. Ecological and evolutionary responses of Mediterranean plants to global change. Environ. Exp. Bot. 2014, 103, 53-67. [CrossRef]

7. Fahn, A. Structural and functional properties of trichomes of xeromorphic leaves. Ann. Bot. 1986, 57, 631-637. [CrossRef]

8. Tattini, M.; Matteini, P.; Saracini, E.; Traversi, M.L.; Giordano, C.; Agati, G. Morphology and biochemistry of non-glandular trichomes in Cistus salvifolius L. leaves growing in extreme habitats of the Mediterranean basin. Plant Biol. 2007, 9, 411-419. [CrossRef]

9. Tattini, M.; Guidi, L.; Morassi-Bonzi, L.; Pinelli, P.; Remorini, D.; Degl'Innocenti, E.; Giordano, C.; Massai, R.; Agati, G. On the role of flavonoids in the integrated mechanisms of response of Ligustrum vulgare and Phillyrea latifolia to high solar radiation. New Phytol. 2005, 167, 457-470. [CrossRef]

10. Li, Z.; Wakao, S.; Fischer, B.B.; Nyiogi, K.K. Sensing and responding to excess light. Annu. Rev. Plant Biol. 2009, 60, 239-260. [CrossRef]

11. Mittler, R. Abiotic stress, the field environment and stress combination. Trends Plant Sci. 2006, 11, 15-19. [CrossRef]

12. Pinheiro, C.; Chaves, M.M. Photosynthesis and drought: Can we make metabolic connections from available data? J. Exp. Bot. 2011, 62, 869-882. [CrossRef] 
13. Miller, G.; Suzuki, N.; Ciftci-Ylmaz, S.; Mittler, R. Reactive oxygen species homeostasis and signalling during drought and salinity stresses. Plant Cell Environ. 2010, 33, 453-467. [CrossRef] [PubMed]

14. Tattini, M.; Gravano, E.; Pinelli, P.; Mulinacci, N.; Romani, A. Flavonoids accumulate in leaves and glandular trichomes of Phillyrea latifolia exposed to excess solar radiation. New Phytol. 2000, 148, 69-77. [CrossRef]

15. Adams, W.W.; Zarter, C.R.; Ebbert, V.; Demmig-Adams, B. Photoprotective strategies of overwintering evergreens. Bioscience 2004, 54, 41-49. [CrossRef]

16. Esteban, R.; Barrutia, O.; Artetxe, U.; Fernández-Marín, B.; Hernández, A.; García-Plazaola, J.I. Internal and external factors affecting photosynthetic pigment composition in plants: A meta-analytical approach. New Phytol. 2015, 206, 268-280. [CrossRef]

17. Agati, G.; Tattini, M. Multiple functional roles of flavonoids in photoprotection. New Phytol. 2010, 186, 786-793. [CrossRef] [PubMed]

18. Agati, G.; Azzarello, E.; Pollastri, S.; Tattini, M. Flavonoids as antioxidants in plants: Location and functional significance. Plant Sci. 2012, 196, 67-76. [CrossRef]

19. Pokhilko, A.; Bou-Torrent, J.; Pulido, P.; Rodríguez-Concepción, M.; Ebenhöh, O. Mathematical modeling of the diurnal regulation of the MEP pathway in Arabidopsis. New Phytol. 2015, 206, 1075-1085. [CrossRef] [PubMed]

20. Cazzonelli, C.I.; Pogson, B.J. Source to sink: Regulation of carotenoid biosynthesis in plants. Trends Plant Sci. 2010, 15, 266-274. [CrossRef] [PubMed]

21. Havaux, M.; Dall'Osto, L.; Bassi, R. Zeaxanthin has enhanced antioxidant capacity with respect to all other xanthophylls in Arabidopsis leaves and functions independent of binding to PSII antennae. Plant Physiol. 2007, 145, 1506-1520. [CrossRef]

22. Ramel, F.; Birtic, S.; Cuiné, S.; Triantaphylidès, C.; Ravanat, J.L.; Havaux, M. Chemical quenching of singlet oxygen by carotenoids in plants. Plant Physiol. 2012, 158, 1267-1278. [CrossRef]

23. Havaux, M.; Dall'Osto, L.; Cuiné, S.; Giuliano, G.; Bassi, R. The effect of zeaxanthin as the only xanthophyll on the structure and function of the photosynthetic apparatus in Arabidopsis thaliana. J. Biol. Chem. 2004, 279, 13878-13888. [CrossRef] [PubMed]

24. Brunetti, C.; Guidi, L.; Sebastiani, F.; Tattini, M. Isoprenoids and phenylpropanoids are key component of the antioxidant defense system of plants facing severe light stress. Environ. Exp. Bot. 2015, 119, 54-62. [CrossRef]

25. Tattini, M.; Loreto, F.; Fini, A.; Guidi, L.; Brunetti, C.; Velikova, V.; Gori, A.; Ferrini, F. Isoprenoids and phenylpropanoids are part of the antioxidant defense orchestrated daily by drought-stressed Platanus $\times$ acerifolia plants during Mediterranean summers. New Phytol. 2015, 207, 613-626. [CrossRef]

26. Niinemets, Ü.; Kollist, H.; García-Plazaola, J.I.; Hernández, A.; Becerril, J.M. Do the capacity and kinetics for modification of xanthophyll cycle pool size depend on growth irradiance in temperate trees? Plant Cell Environ. 2003, 26, 1787-1801. [CrossRef]

27. Johnson, M.P.; Havaux, M.; Triantaphylidès, C.; Ksas, B.; Pascal, A.A.; Robert, B.; Davison, P.A.; Ruban, A.V.; Horton, P. Elevated zeaxanthin bound to oligomeric LHCII enhances the resistance of Arabidopsis to photooxidative stress by a lipid-protective antioxidant mechanism. J. Biol. Chem. 2007, 282, 22605-22618. [CrossRef]

28. Havaux, M.; Niyogi, K.K. The violaxanthin cycle protects plants from photooxidative damage by more than one mechanism. Proc. Natl. Acad. Sci. USA 1999, 96, 8762-8767. [CrossRef]

29. Beckett, M.; Loreto, F.; Velikova, V.; Brunetti, C.; Di Ferdinando, M.; Tattini, M.; Calfapietra, C.; Farrant, J.M. Photosynthetic limitations and volatile and non-volatile isoprenoids in the poikilochlorophyllous resurrection plant Xerophyta humilis during dehydration and rehydration. Plant Cell Environ. 2012, 35, 2061-2074. [CrossRef]

30. Fernández-Marín, B.; Hernández, A.; Garcia-Plazaola, J.I.; Esteban, R.; Míguez, F.; Artetxe, U.; Gómez-Sagasti, M.T. Photoprotective strategies of Mediterranean plants in relation to morphological traits and natural environmental pressure: A meta-analytical approach. Front. Plant Sci. 2017, 8, 1051. [CrossRef]

31. Davison, P.A.; Hunter, C.N.; Horton, P. Overexpression of $\beta$-carotene hydroxylase enhances stress tolerance in Arabidopsis. Nature 2002, 418, 203-206. [CrossRef] [PubMed]

32. Du, H.; Wang, N.; Cui, F.; Li, X.; Xiao, J.; Xiong, L. Characterization of the $\beta$-carotene hydroxylase gene DSM2 conferring drought and oxidative stress resistance by increasing xanthophylls and abscisic acid synthesis in rice. Plant Physiol. 2010, 154, 1304-1318. [CrossRef] [PubMed]

33. Zhang, R.R.; Wang, Y.H.; Li, T.; Tan, G.F.; Tao, J.P.; Su, X.S.; Xu, Z.S.; Tian, Y.S.; Xiong, A.S. Effects of simulated drought stress on carotenoid contents and expression of related genes in carrot taproots. Protoplasma 2021, 258, 379-390. [CrossRef] [PubMed]

34. Deng, Y.; Lu, S. Biosynthesis and regulation of phenylpropanoids in plants. Crit. Rev. Plant Sci. 2017, 36, 257-290. [CrossRef]

35. Falcone-Ferreyra, M.L.; Rius, S.P.; Casati, P. Flavonoids: Biosynthesis, biological functions, and biotechnological applications. Front. Plant Sci. 2012, 3, 222. [CrossRef] [PubMed]

36. Siipola, S.M.; Kotilainen, T.; Sipari, N.; Morales, L.O.; Lindfors, A.V.; Robson, T.M.; Aphalo, P.J. Epidermal UV-A absorbance and whole-leaf flavonoid composition in pea respond more to solar blue light than to solar UV radiation. Plant Cell Environ. 2015, 38, 941-952. [CrossRef] [PubMed]

37. Agati, G.; Stefano, G.; Biricolti, S.; Tattini, M. Mesophyll distribution of antioxidant flavonoid glycosides in Ligustrum vulgare leaves under contrasting sunlight irradiance. Ann. Bot. 2009, 104, 853-861. [CrossRef]

38. Tattini, M.; Galardi, C.; Pinelli, P.; Massai, R.; Remorini, D.; Agati, G. Differential accumulation of flavonoids and hydroxycinnamates in leaves of Ligustrum vulgare under excess light and drought stress. New Phytol. 2004, 163, 547-561. [CrossRef] 
39. Ferreres, F.; Figueiredo, R.; Bettencourt, S.; Carqueijeiro, I.; Oliveira, J.; Jil-Izqueirdo, A.; Pereira, D.M.; Valentao, P.; Andrade, P.B.; Duarte, P. Identification of phenolic compounds in isolated vacuoles of the medicinal plant Catharanthus roseus and their interaction with vacuolar class III peroxidase: $\mathrm{An} \mathrm{H}_{2} \mathrm{O}_{2}$ affair? J. Exp. Bot. 2011, 62, 2841-2854. [CrossRef]

40. Agati, G.; Brunetti, C.; Fini, A.; Gori, A.; Guidi, L.; Landi, M.; Sebastiani, F.; Tattini, M. Are flavonoids effective antioxidants in plants? Twenty years of our investigation. Antioxidants 2020, 9, 1098. [CrossRef]

41. Agati, G.; Galardi, C.; Gravano, E.; Romani, A.; Tattini, M. Flavonoid distribution in tissues of Phillyrea latifolia L. leaves as estimated by microspectrofluorometry and multispectral fluorescence microimaging. Photochem. Photobiol. 2002, 76, 350-360. [CrossRef]

42. Agati, G.; Brunetti, C.; Di Ferdinando, M.; Ferrini, F.; Pollastri, S.; Tattini, M. Functional roles of flavonoids in photoprotection: New evidence, lessons from the past. Plant Physiol. Biochem. 2013, 72, 35-45. [CrossRef] [PubMed]

43. Adams Lii, W.W.; Volk, M.; Hoehn, A.; Demmig-Adams, B. Leaf orientation and the response of the xanthophyll cycle to incident light. Oecologia 1992, 90, 404-410. [CrossRef]

44. Faria, T.; Garcia-Plazaola, J.I.; Abadia, A.; Cerasoli, S.; Pereira, J.S.; Chaves, M.M. Diurnal changes in photoprotective mechanisms in leaves of cork oak (Quercus suber) during summer. Tree Physiol. 1999, 16, 115-123. [CrossRef]

45. Adams Lii, W.W.; Demmig-Adams, B.; Logan, B.A.; Barker, D.H.; Osmond, C.B. Rapid changes in xanthophyll cycle-dependent energy dissipation and photosystem II efficiency in two vines, Stephania japonica and Smilax australis, growing in the understory of an open Eucalyptus forest. Plant Cell Environ. 1999, 22, 125-136. [CrossRef]

46. Kyparissis, A.; Drilias, P.; Manetas, Y. Seasonal fluctuations in photoprotective (xanthophyll cycle) and photoselective (chlorophylls) capacity in eight Mediterranean plant species belonging to two different growth forms. Funct. Plant Biol. 2000, 27, 265-272. [CrossRef]

47. Peguero-Pina, J.J.; Sancho-Knapik, D.; Morales, F.; Flexas, J.; Gil-Pelegrín, E. Differential photosynthetic performance and photoprotection mechanisms of three Mediterranean evergreen oaks under severe drought stress. Funct. Plant Biol. 2009, 36, 453-462. [CrossRef]

48. Sauceda, J.U.; Rodriguez, H.G.; Lozano, R.R.; Silva, I.C.; Meza, M.V.; Larga, L. Seasonal trends of chlorophylls a and b and carotenoids in native trees and shrubs of Northeastern Mexico. J. Biol. Sci. 2008, 8, 258-267. [CrossRef]

49. Garcia-Plazaola, J.I.; Faria, T.; Abadia, J.; Chaves, M.M.; Pereira, J.S. Seasonal changes in xanthophyll composition and photosynthesis of cork oak (Quercus suber L.) leaves under Mediterranean climate. J. Exp. Bot. 1997, 48, 1667-1674. [CrossRef]

50. Prinsloo, G.; Nogemane, N. The effects of season and water availability on chemical composition, secondary metabolites and biological activity in plants. Phytochem. Rev. 2018, 17, 889-902. [CrossRef]

51. Gori, A.; Tattini, M.; Centritto, M.; Ferrini, F.; Marino, G.; Mori, J.; Guidi, L.; Brunetti, C. Seasonal and daily variations in primary and secondary metabolism of three maquis shrubs unveil different adaptive responses to Mediterranean climate. Conserv. Physiol. 2019, 7, coz070. [CrossRef] [PubMed]

52. Gori, A.; Nascimento, L.B.S.; Ferrini, F.; Centritto, M.; Brunetti, C. Seasonal and diurnal variation in leaf phenolics of three medicinal Mediterranean wild species: What is the best harvesting moment to obtain the richest and the most antioxidant extracts? Molecules 2020, 25, 956. [CrossRef] [PubMed]

53. Fischbach, R.J.; Kossmann, B.; Panten, H.; Steinbrecher, R.; Heller, W.; Seidlitz, H.K.; Sandermann, H.; Hertkorn, N.; Schnitzler, J.P. Seasonal accumulation of ultraviolet-B screening pigments in needles of Norway spruce (Piceaabies (L.) Karst.). Plant Cell Environ. 1999, 22, 27-37. [CrossRef]

54. Bouderias, S.; Teszlak, P.; Jakab, G.; Korosi, L. Age- and season-dependent pattern of flavonol glycosides in Cabernet Sauvignon grapevine leaves. Sci. Rep. 2020, 10, 14241. [CrossRef]

55. Savoi, S.; Wong, D.C.J.; Arapitsas, P.; Miculan, M.; Bucchetti, B.; Peterlungher, E.; Fait, A.; Mattivi, F.; Castellarin, S.D. Transcriptome and metabolite profiling reveals that prolonged drought modulates the phenylpropanoid and terpenoid pathway in white grapes (Vitis vinifera L.). BMC Plant Biol. 2016, 16, 67. [CrossRef]

56. Barnes, P.W.; Flint, S.D.; Tobler, M.A.; Ryel, R.J. Diurnal adjustment in ultraviolet sunscreen protection is widespread among higher plants. Oecologia 2016, 181, 55-63. [CrossRef]

57. Barnes, P.W.; Tobler, M.A.; Keefover-Ring, K.; Flint, S.D.; Barkley, A.E.; Ryel, R.J.; Lindroth, R.L. Rapid modulation of ultraviolet shielding in plants is influenced by solar ultraviolet radiation and linked to alterations in flavonoids. Plant Cell Environ. 2016, 39, 222-230. [CrossRef]

58. Csepregi, K.; Teszlak, P.; Korosi, L.; Hideg, E. Changes in grapevine leaf phenolic profiles during the day are temperature rather than irradiance driven. Plant Physiol. Biochem. 2019, 137, 169-178. [CrossRef]

59. Liebelt, D.J.; Jordan, J.T.; Doherty, C.J. Only a matter of time: The impact of daily and seasonal rhythms on phytochemicals. Phytochem. Rev. 2019, 18, 1409-1433. [CrossRef]

60. Romani, A.; Pinelli, P.; Mulinacci, N.; Vincieri, F.F.; Gravano, E.; Tattini, M. HPLC analysis of flavonoids and secoiridoids in leaves of Ligustrum vulgare L. (Oleaceae). J. Agric. Food Chem. 2000, 48, 4091-4096. [CrossRef]

61. Penuelas, J.; Lluisa, J.; Pinol, J.; Filella, I. Photochemical reflectance index and leaf photosynthetic radiation-use-efficiency assessment in Mediterranean trees. Int. J. Remote Sens. 1997, 18, 2863-2868. [CrossRef]

62. Havaux, M.; Tardy, F. Loss of chlorophyll with limited reduction of photosynthesis as an adaptive response of Syrian barley landraces to high-light and heat stress. Funct. Plant Biol. 1999, 26, 569-578. [CrossRef] 
63. Zivcak, M.; Brestic, M.; Kalaji, H.M. Photosynthetic responses of sun-and shade-grown barley leaves to high light: Is the lower PSII connectivity in shade leaves associated with protection against excess of light? Photosynth. Res. 2014, 119, 339-354. [CrossRef] [PubMed]

64. Kouřil, R.; Wientjes, E.; Bultema, J.B.; Croce, R.; Boekema, E.J. High-light vs. low-light: Effect of light acclimation on photosystem II composition and organization in Arabidopsis thaliana. Biochim. Biophys. Acta 2013, 1827, 411-419. [CrossRef]

65. Fini, A.; Ferrini, F.; Di Ferdinando, M.; Brunetti, C.; Giordano, C.; Gerini, F.; Tattini, M. Acclimation to partial shading or full sunlight determines the performance of container-grown Fraxinus ornus to subsequent drought stress. Urban For. Urban Green 2014, 13, 63-70. [CrossRef]

66. Brunetti, C.; Loreto, F.; Ferrini, F.; Gori, A.; Guidi, L.; Remorini, D.; Centritto, M.; Fini, A.; Tattini, M. Metabolic plasticity in the hygrophyte Moringa oleifera exposed to water stress. Tree Physiol. 2016, 38, 1640-1654. [CrossRef]

67. Halliwell, B.; Gutteridge, J.M.C. Free Radicals in Biology and Medicine, 4th ed.; Oxford University Press: Oxford, UK, 2007.

68. Havaux, M.; García-Plazaola, J.I. Beyond non-photochemical fluorescence quenching: The overlapping antioxidant functions of zeaxanthin and tocopherols. In Non-Photochemical Quenching and Energy Dissipation in Plants, Algae and Cyanobacteria. Advances in Photosynthesis and Respiration (Including Bioenergy and Related Processes); Demmig-Adams, B., Garab, G., Adams Lii, W.W., Govindjee, Eds.; Springer: Dordrecht, The Netherlands, 2014; Volume 40, pp. 583-603. [CrossRef]

69. Havaux, M. Carotenoids as membrane stabilizers in chloroplasts. Trends Plant Sci. 1998, 3, 147-151. [CrossRef]

70. Dall'Osto, L.; Cazzaniga, S.; Havaux, M.; Bassi, R. Enhanced photoprotection by protein-bound vs free xanthophyll pools: A comparative analysis of chlorophyll $b$ and xanthophyll biosynthesis mutants. Mol. Plant 2010, 3, 576-593. [CrossRef] [PubMed]

71. Triantaphylidès, C.; Havaux, M. Singlet oxygen in plants: Production, detoxification and signaling. Trends Plant Sci. 2009, 14, 219-228. [CrossRef] [PubMed]

72. Ramel, F.; Mialoundama, A.S.; Havaux, M. Nonenzymic carotenoid oxidation and photooxidative stress signalling in plants. J. Exp. Bot. 2013, 64, 799-805. [CrossRef]

73. Kotilainen, T.; Tegelberg, R.; Julkunen-Tiitto, R.; Lindfors, A.; O'Hara, R.B.; Aphalo, P.J. Seasonal fluctuations in leaf phenolic composition under UV manipulations reflect contrasting strategies of alder and birch trees. Physiol. Plant 2010, 140, 297-309. [CrossRef]

74. Varela, M.C.; Arslan, I.; Reginato, M.A.; Cenzano, A.M.; Luna, M.V. Phenolic compounds as indicators of drought resistance in shrubs from Patagonian shrublands (Argentina). Plant Physiol. Biochem. 2019, 104, 81-91. [CrossRef]

75. De Abreu, I.N.; Mazzafera, P. Effect of water and temperature stress on the content of active constituents of Hypericum brasiliense Choisy. Plant Physiol. Biochem. 2005, 43, 241-248. [CrossRef] [PubMed]

76. Rao, M.J.; Xu, Y.; Tang, X.; Huang, Y.; Liu, J.; Deng, X.; Xu, Q. CsCYT75B1, a Citrus CYTOCHROME P450 gene, is involved in accumulation of antioxidant flavonoids and induces drought tolerance in transgenic Arabidopsis. Antioxidants 2020, 9, 161. [CrossRef] [PubMed]

77. Mátai, A.; Nagy, D.; Hideg, E. UV-B strengthens antioxidant responses to drought in Nicotiana benthamiana leaves not only as supplementary irradiation but also as pre-treatment. Plant Physiol. Biochem. 2019, 134, 9-19. [CrossRef] [PubMed]

78. Agati, G.; Matteini, P.; Goti, A.; Tattini, M. Chloroplast-located flavonoids can scavenge singlet oxygen. New Phytol. 2007, 174, 77-89. [CrossRef] [PubMed]

79. Akhtar, T.A.; Lees, H.A.; Lampi, M.A.; Enstone, D.; Brain, R.A.; Greenberg, B.M. Photosynthetic redox imbalance influences flavonoid biosynthesis in Lemma gibba. Plant Cell Environ. 2010, 33, 1205-1219. [CrossRef] [PubMed]

80. Babu, S.; Akhtar, T.A.; Lampi, M.A.; Tripuranthakam, S.; Dixon, G.R.; Greenberg, B.M. Similar stress responses are elicited by copper and ultraviolet radiation in the aquatic plant Lemma gibba: Implication of reactive oxygen species as common signals. Plant Cell Physiol. 2003, 44, 1320-1329. [CrossRef]

81. Viola, A.L.; Camoirano, A.; Gonzalez, D.H. Redox-dependent modulation of anthocyanin biosynthesis by the TCP transcription factor TCP15 during exposure to high light intensity conditions in Arabidopsis. Plant Physiol. 2016, 170, 74-85. [CrossRef]

82. Page, M.; Sultana, N.; Paszkievicz, K.; Florance, H.; Smirno, N. The influence of ascorbate on anthocyanin accumulation during high light acclimation in Arabidopsis thaliana: Further evidence for redox control of anthocyanin synthesis. Plant Cell Environ. 2012, 35, 388-404. [CrossRef]

83. Falcone-Ferreyra, M.L.; Rius, S.; Emiliani, J.; Pourcel, L.; Feller, A.; Morohashi, K.; Casati, P.; Grotewold, E. Cloning and characterization of a UV-B-inducible maize flavonol synthase. Plant J. 2010, 62, 77-91. [CrossRef]

84. Pollastri, S.; Tattini, M. Flavonols: Old compounds for old roles. Ann. Bot. 2011, 108, 1225-1233. [CrossRef] [PubMed]

85. Fini, A.; Guidi, L.; Ferrini, F.; Brunetti, C.; Di Ferdinando, M.; Biricolti, S.; Pollastri, S.; Calamai, L.; Tattini, M. Drought stress has contrasting effects on antioxidant enzymes activity and phenylpropanoid biosynthesis in Fraxinus ornus leaves: An excess light stress affair? J. Plant Physiol. 2012, 169, 929-939. [CrossRef] [PubMed]

86. Fini, A.; Brunetti, C.; Di Ferdinando, M.; Ferrini, F.; Tattini, M. Stress-induced biosynthesis of flavonoids and the antioxidant machinery of plants. Plant Signal. Behav. 2011, 6, 709-711. [CrossRef] [PubMed]

87. Polle, A. Dissecting the superoxide dismutase-ascorbate-glutathione-pathway in chloroplasts by metabolic modeling: Computer simulations as a step towards flux analysis. Plant Physiol. 2001, 169, 929-939. [CrossRef]

88. Peltzer, D.; Polle, A. Diurnal fluctuations of antioxidative systems in leaves of field-grown beech trees (Fagus sylvatica): Responses to light and temperature. Physiol. Plant 2001, 111, 158-164. [CrossRef] 
89. Peltzer, D.; Dreyer, E.; Polle, A. Differential temperature dependencies of antioxidative enzymes in two contrasting species. Plant Physiol. Biochem. 2002, 40, 141-150. [CrossRef]

90. Martinez, V.; Mestre, T.C.; Rubio, F.; Gironas-Villaplana, A.; Moreno, D.A.; Mittler, R.; Rivero, R.M. Accumulation of flavonols over hydroxycinnamic acids favors oxidative damage protection under abiotic stress. Front. Plant Sci. 2016, 7, 838. [CrossRef]

91. Gouot, J.C.; Smith, J.P.; Holzapfel, B.P.; Walker, A.R.; Barril, C. Grape berry flavonoids: A review of their biochemical responses to high and extreme high temperatures. J. Exp. Bot. 2019, 70, 397-423. [CrossRef]

92. Samson, G.; Cerovic, Z.G.; El Rouby, W.M.A.; Millet, P. Oxidation of polyphenols and inhibition of photosystem II under acute photooxidative stress. Planta 2020, 251, 16. [CrossRef]

93. Sakihama, Y.; Mano, J.; Sano, S.; Asada, K.; Yamasaki, H. Reduction of phenoxyl radicals mediated by mono dehydroascorbate reductase. Biochem. Biophys. Res. Commun. 2000, 279, 949-954. [CrossRef]

94. Zechmann, B. Compartment-specific importance of ascorbate during environmental stress in plants. Antiox. Redox Signal. 2018, 29, 1488-1501. [CrossRef]

95. Zechmann, B. Subcellular roles of glutathione in mediating plant defense during biotic stress. Plants 2020, 9, 1067. [CrossRef] [PubMed]

96. Gould, K.S.; Markham, K.R.; Smith, R.H.; Goris, J.J. Functional roles of anthocyanins in leaves of Quintinia serrata A. Cunn. J. Exp. Bot. 2000, 51, 1107-1115. [CrossRef]

97. Schoch, G.; Goepfert, S.; Morant, M.; Hehn, A.; Meyer, D.; Ullmann, P.; Werck-Reichhart, D. CYP98A3 from Arabidopsis thaliana is a $3^{\prime}$-hydroxylase of phenolic esters, a missing link in the phenylpropanoid pathway. J. Biol. Chem. 2001, 276, 36566-36574. [CrossRef] [PubMed]

98. Besseau, S.; Hoffmann, L.; Geoffroy, P.; Lapierre, C.; Pollet, B.; Legrand, M. Flavonoid accumulation in Arabidopsis repressed in lignin synthesis affects auxin transport and plant growth. Plant Cell 2007, 19, 148-162. [CrossRef]

99. Khorobrykh, S.; Havurinne, V.; Mattila, H.; Tyystjärvi, E. Oxygen and ROS in Photosynthesis. Plants 2020, 9, 91. [CrossRef] [PubMed]

100. Ålenius, C.M.; Vogelmann, T.C.; Bornman, J.F. A three-dimensional representation of the relationship between penetration of UV-B radiation and UV-screening pigments in leaves of Brassica napus. New Phytol. 1995, 131, 297-302. [CrossRef] 